\section{THE CAUSATION OF "TRENCH SHIN."}

To the Editor of THE LANOwT.

SIR,- The view that gaiters or puttees are the determining cause of the "shin" pain, so characteristic of a certain class of trench fever, receives support from an article in THE LANCE'T ${ }^{1}$ by Lieutenant-Colonel Chambers, entitled "Trench Shin an Infectious Fibrositis." In this very interesting and valuable contribution Oolonel Chambers states that "trench shin" is a different disease from "trench fever," and is caused in part by wearing tight puttees which obstruct the venous circulation and cause a continuous loss of heat, thus lowering the resistance of the fibrons tissue to infection. The assumptions that "trench shin "is a different disease from "trench fever," and that puttees play anything more than a very subsidiary part in the causation of shin pain, are both open to grave objections. Cases of "trench fever" may be divided into three groups: (1) with simple fever alone; (2) with fever and "muscle" pain; (3) with fever and "shin pain." Frequently a patient at the commencement would be classified in Group 1. Later he develops what I have for, convenience called "muscle pain," but which I agree is really due to a fibrositis; and later still he develops the pain in the shins or "shin pain." Or the order may be altered or the characteristics of Groups 2 and 3 may be combined.

If puttees were important factors all cases suffering from trench fever wonld develop "trench shin" as most men wear puttees, but only a certain number develop "shin " pain and tenderness. In putting on puttees one area of maximum constriction is about the junction of the middle and lower thirds of leg, the other area being below the tibial condyle, the intervening portion of the puttee being more or less loose owing to the action of the calf and other muscles. Assuming that constriction has anything to do with the "shin" pain, the areas of maximum shin tenderness ought to be the junction of the lower and middle thirds of tibia and in the upper third. Colonel Chambers says that the lower third is protected by the boot and escapes. My experience of cases during part of a winter in Amiens was that the lower third was more often and more severely affected than any other part of the bone, and that the upper third rarely suffered.

The soldiers of the Belgian Army and some of our Scotch regiments wear a puttee covering lower third of leg only. Amongst the latter I have seen most severe "shin" pain affecting the whole iength of bone. The same applies, I believe, to cases in the Belgian Army. Then, again, men for special reasons have not worn puttees, and have when affected in some instances had the most violent and extensive "shin" pain. Many men who have been in bed recovering from wounds develop trench fever and quite as commonly develop "trench shin" as those men who have worn puttees. I bave heard of nursing sisters who have developed trench fever with severe shin pain.

In many cases only certain localised areas about the size of a shilliag will be found tender. In numerous cases one eg is very badly affected and the other leg is only slightly so or free from pain altogether. Pain and tenderness over the tibia are very common, and the constriction due to puttees is suggested as the reason, but pain and tenderness in other bones such as humerus, ulna, \&e., are quite frequent and could not be explained by any theory of constriction. It seems that there must be some other reason for this pain than constriction and that "trench shin" cannot be a clinical entity.

In Group 2 of cases of trench fever-viz., those with "muscle pain"-it will be found that the pain is most intense in places that have the maximum amount of fibrous tissue, thus confirming Colonel Chambers's theory of an infectious fibrositis. Such places, for example, are the sole of the foot, the thick aponeurosis covering the upper half or so of the anterior group of tibial muscles, the quadriceps tendonse the fascia lata, and the thick intermuscular septa of the thigh, the thiek aponeurosis of the forearm which is attached to the ulna and helps to give origin to some of the forearm muscles, the tendinous intersections of the deltoid, the intermuscular septa of the arm, the ligamentum nuche, and the thick masses of fibrous tissue among the spinal muscles. In all these places pain is present, and is readily explained on the theory of it being the result of infectious fibrositis. The tendinous origins of the abdominal muscles from the lower ribs are also frequently affected, giving rise to symptoms resembling pleurisy or pleurodynia. The pain in the calves on pressure may be explained by the various aponeuroses and intermuscular septa deeply situated in these regions being inflamed.

The theory of trench fever being an "infectious fibrositis" may also be used to explain the neuritic symptoms. The

1 Chambers : The Lafcet, 1917, i., 752. fibrous tissue surrounding nerves may be affected and thus account for the tenderness of the ulnar, median, sciatic, and other nerves in various parts of the body, and also for the paræsthesia, tingling, \&c., often present in the hands and feet.

The pain present in cases of Group 3-viz., those with fever and "shin" pain-is really the same kind of thing, but affecting mainly the periosteum, which is histologically largely fibrous tissue. The hyperæmia causes swelling and affects the nerve-endings, thus accounting for the severe "bone" pain. What the determining factor is in causing the fibrous tissue of the periosteum to be more liable to be affected in some cases than the fibrous tissue in other situations at present is unknown, but is analogous to the selective action of strychnine, for example, on nerve tissues, of which there are many examples in medicine.

For the preceding reasons it seems clear that "trench shin" is not a distinct clinical entity, but merely a variety of trench fever, and that puttees have little, if any, share in the causation of "shin pain."

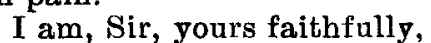

J. ALraN BERRY, Captain, N.Z.M.C.

March 8th, 1918.

\section{CHRONIC GONORRHCEAL INFECTION OF THE PROSTATE AND VESICLES.}

\section{To the Editor of THE LANCET.}

SIR,-I consider Mr. Rolf Creasy's letter on the above subject in your issue of March 23rd both encouraging and illuminating. Five years ago last December I published my first article on this subject in the Ophthalmosoope. Consequently it only appealed to a very limited section of the profession. Also five years ago Mr. Canny Ryall had the first cases of recurrent irido-cyclitis sent to him from Moorfields Hospital; the two incidents may or may not be related. Since then many such R.I.C. cases have been treated at All Saints' Hospital. In view of these facts, what surprises me is that in a period of five years there has not been a single affirmation of my 1912 findings, only one negation, refuted, and a few unscientific "pious opinions" of a negative character. My statement, "I have never seen a case of recurrent gonorrhoeal irido-cyclitis in which an y attempt has been made to attempt a cure," still holds good. I now know with pleasure for the first time that attempts at cure, and no doubt cures, have been made by others, but in no case which has come under my care had there been any previous attempt.

In the four cases quoted in my paper the vesiculæ were not apparently infected, though Dr. G. Stoker reports such an infection in another later case. In the article of 1912 I, however, mentioned the vesiculæ; describing the tech nique for demonstrating the gonococcus, I stated : "Thirdly, even if the urine is quite clear, one should go a step further and massage the prostate and vesiculæ seminales via the rectum." In my early cases, wishing to obtain first-hand knowledge and not being in touch with the genito-urinary world, I undertook the massage myself, but I found I had not the necessary experience to diagnose abnormalities of the prostate and vesiculæ; hence the scanty reports in my 1912 cases. Cases of irido-cyclitis due to the staphylococcus and coli communis-organisms which Mr. Ryall also finds in these cases-are clinically quite different from the gonococcal cases ; they are readily diagnosed with the help of an opsonic index, the cause is treated efficiently, and consequently recurrence is uncommon and not at all a feature of these infections.

I am, Sir, yours faithfully,
Bolton-street, W., March 23rd, 1918. A. S. COBBLEDTCK.

\section{THE CAUSE AND PREVENTION OF MYOPIA.}

\section{To the Editor of THE LANOET.}

SIR, - I have read with much pleasure the recent important contributions to the discussion. The point which I do not seem to have made clear to Dr. Giri is that it is the parts where the greatest pressure is applied which give way. If he will refer to my diagram again he will see that the pressure at the outflow at $A$ is negative. The head of the oplic nerve corresponds to a point in the cistern $\mathbf{E}$, and closing the aperture $A$ whilst greatly increasing the pressure at this point and at $B$ does not affect the pressure at $F$ at all. 